\title{
Problematyka ochrony własności intelektualnej na studiach zarządzania informacją i kierunkach pokrewnych w Polsce
}

\author{
Diana Pietruch-Reizes \\ ORCID 0000-0002-4674-000X \\ Instytut Studiów Informacyjnych \\ Wydziat Zarzadzania i Komunikacji Społecznej \\ Uniwersytet Jagielloński
}

\begin{abstract}
Abstrakt
Cel/Teza: Celem artykułu jest zwrócenie uwagi na znaczenie wiedzy z zakresu ochrony własności intelektualnej - obejmującej własność przemysłową i prawo autorskie - w kontekście nowych, dynamicznie rozwijających się technologii informacyjno-komunikacyjnych oraz gospodarki cyfrowej na prowadzonych w polskich uczelniach studiach uniwersyteckich kształcących tzw. profesjonalistów informacji - specjalistów zarządzania informacją, bibliotekoznawców, brokerów informacji czy specjalistów zarządzania dokumentacją.

Koncepcja/Metody badań: Metoda analizy i krytyki piśmiennictwa została wykorzystana do omówienia zagadnienia ochrony własności intelektualnej. Na podstawie danych z systemu informacji o szkolnictwie wyższym POL-on oraz stron internetowych poszczególnych uniwersytetów wyróżniono kierunki studiów w wymienionym zakresie. Analizowano plany studiów i moduły kształcenia pod kątem treści z zakresu ochrony własności intelektualnej.

Wyniki i wnioski: Przedmiotem badania były polskie standardy kształcenia pod kątem treści z zakresu ochrony własności intelektualnej. Wynika z nich, że obejmują one w kategoriach wiedzy, umiejętności i kompetencji społecznych efekty uczenia się w odniesieniu do ochrony własności przemysłowej i prawa autorskiego. Stwierdzono, że na większości kierunków prowadzone jest nauczanie z zakresu ochrony własności intelektualnej, różnice występują w odniesieniu do nazwy przedmiotu (przeważa nazwa „ochrona własności intelektualnej”), jego statusu, zakresu kształcenia, formy czy liczby godzin. Na przykładzie kierunku zarządzanie informacją, realizowanego przez Instytut Studiów Informacyjnych (dawny Instytut Informacji Naukowej i Bibliotekoznawstwa) na Wydziale Zarządzania i Komunikacji Społecznej Uniwersytetu Jagiellońskiego, analizując plan studiów I i II stopnia oraz moduły kształcenia, przedstawiono założone efekty kształcenia w odniesieniu do ochrony własności intelektualnej, uzasadniając potrzeby realizacji przedmiotów w tym obszarze oraz wskazując na zakres wiedzy przekazywanej studentom zarządzania informacją.

Oryginalność/Wartość poznawcza: Przedstawione zagadnienie nie było do tej pory przedmiotem szerszych rozważań.
\end{abstract}

\section{Słowa kluczowe}

Ochrona własności intelektualnej. Polska. Standardy kształcenia. Studia uniwersyteckie. Unia Europejska. Zarządzanie informacją.

Otrzymany: 30 stycznia 2020. Zrecenzowany: 27 lutego 2020. Poprawiony: 5 kwietnia 2020. Zaakceptowany: 11 maja 2020. 


\section{Szkolnictwo wyższe - kontekst europejski}

W odnowionym programie Unii Europejskiej dla szkolnictwa wyższego, przyjętym w 2017 r., wskazano na kluczową rolę systemów kształcenia i szkolenia w budowaniu sprawiedliwego, otwartego i demokratycznego społeczeństwa, a także ich znaczenie dla zrównoważonego wzrostu i zatrudnienia. Szczególnie ważne są nowe inicjatywy i programy w szkolnictwie wyższym w odniesieniu do kształcenia, badań naukowych, innowacji. W komunikacie Komisji Europejskiej podkreślono, iż:

zdolność do przedsiębiorczego działania, zarządzania złożonymi informacjami, niezależnego i kreatywnego myślenia, inteligentnego wykorzystywania zasobów - w tym zasobów cyfrowych - oraz do skutecznego komunikowania się i budowania odporności jest dziś ważniejsza niż kiedykolwiek (Komunikat KE, 2017a, 2).

Także we wcześniejszych dokumentach Komisja Europejska zwracała uwagę na to, że rosnące znaczenie współpracy uczelni wyższych, uniwersytetów z instytucjami środowiska biznesowego, tj. w ramach tzw. trójkąta wiedzy, obejmującego badania naukowe, edukację i innowacje, w szczególności z sektorem małych i średnich przedsiębiorstw, a także z innymi podmiotami prywatnymi, wymaga podejmowania działań promujących zdobywanie przez studentów wiedzy, umiejętności i kompetencji, które będą przydatne na rynku pracy. W tym kontekście programy nauczania powinny być szybciej dostosowywane do wymogów gospodarki opartej na wiedzy, uwzględniając w ofercie edukacyjnej potrzeby określone w strategii inteligentnej specjalizacji, jak czytamy w Komunikacie Komisji Europejskiej z 2011 r.:

pomocne w dostosowywaniu programów nauczania do obecnych i dopiero pojawiających się potrzeb rynku pracy oraz we wspieraniu zdolności do zatrudnienia i przedsiębiorczości może być włączenie pracodawców i instytucji rynku pracy w opracowywanie i realizację programów, wspieranie wymiany pracowników i uwzględnianie w ramach zajęć praktycznego doświadczenia (Komunikat KE, 2011, 5).

Ważne jest umożliwienie studentom rozwijania umiejętności w odniesieniu do przedsiębiorczości, kreatywności oraz innowacyjności w obszarze każdej dyscypliny i każdego cyklu kształcenia, aby w przyszłości mogli wykorzystywać zaawansowane umiejętności i włączyć się w zadania związane z „trójkątem wiedzy”. W związku z tym, instytucje szkolnictwa wyższego powinny dynamiczniej angażować się w dziedzinę innowacji, a to wiąże się także z działaniami w obszarze kształcenia, bowiem

(...) w ramach wszystkich form kształcenia wyższego należy dążyć do wyposażenia studentów w zdolność rozumienia nowych pojęć, krytycznego i kreatywnego myślenia oraz przedsiębiorczego działania pozwalającego opracowywać i stosować nowe koncepcje (Komunikat KE, 2017a, 9).

To stanowi realizację trzech wzajemnie powiązanych priorytetów wyrażającyh strategię Europa 2020, mianowicie: 1) rozwoju inteligentnego identyfikowanego z wzrastającą rolą wiedzy i innowacji, 2) rozwoju zrównoważonego, zapewniającego budowanie gospodarki efektywnie korzystającej z zasobów, opartej o technologie przyjazne środowisku u bardziej konkurencyjnej oraz 3) rozwoju sprzyjającego włączeniu społecznemu (Komunikat KE, 2010).

W kontekście powyższych rozważań można postawić pytanie, czy wiedza, umiejętności i kompetencje w zakresie ochrony własności intelektualnej są niezbędne we współczesnym świecie? Kluczowa rola wiedzy i innowacji dla inteligentnego rozwoju wymaga właściwego zarządzania własnością intelektualną, rozwoju kultury przedsiębiorczości i kształtowania odpowiednich umiejętności. Dlatego programy studiów powinny uwzględniać treści 
z zakresu ochrony własności intelektualnej w szerokim znaczeniu, w tym dotyczące zarządzania własnością intelektualną i transferu wiedzy. W tym miejscu można przypomnieć zalecenie Komisji Europejskiej z 2008 r., w którym podkreślono m.in. znaczenie wspierania rozwoju zdolności związanych z transferem wiedzy oraz zwiększenia świadomości i umiejętności studentów w zakresie własności intelektualnej, transferu wiedzy i przedsiębiorczości (Zalecenie KE, 2008).

Artykuł przedstawia zagadnienie kształcenia studentów zarządzania informacją i kierunków pokrewnych w obszarze ochrony własności intelektualnej. Dokonano przeglądu polskich standardów kształcenia pod kątem treści z zakresu ochrony własności intelektualnej, z ukazaniem efektów w postaci wiedzy, umiejętności i kompetencji. Wykorzystując metodę analizy i krytyki piśmiennictwa, omówiono problematykę własności intelektualnej w aspekcie historycznym i współczesnym. Celem badań było zwrócenie uwagi na znaczenie wiedzy z zakresu ochrony własności intelektualnej na studiach uniwersyteckich kształcących tzw. profesjonalistów informacji. Korzystano z danych systemu informacji o szkolnictwie wyższym POL-on oraz ze stron internetowych poszczególnych uniwersytetów oferujących kierunki studiów w wymienionym zakresie. Autorka artykułu odwołała się także do własnych doświadczeń w zakresie dydaktyki przedmiotu ochrona własności intelektualnej na kierunku zarządzanie informacją na Wydziale Zarządzania i Komunikacji Społecznej Uniwersytetu Jagiellońskiego.

\section{Własność intelektualna - wymiar historyczny, teraźniejszy i przyszły}

We współczesnym świecie prawa własności intelektualnej mają kluczowe znaczenie dla nowoczesnej gospodarki, jej innowacyjności i konkurencyjności. To właśnie innowacje dynamizują rozwój gospodarczy, dzięki nim łatwiej podejmować wyzwania epoki globalizacji. Należy jednak zauważyć, że fundamentalne regulacje prawne w tym obszarze wypracowano w 1. 80. XIX stulecia, mianowicie 20 marca 1883 r. przyjęto Konwencję związkowa paryska o ochronie własności przemystowej, a trzy lata później, 9 września 1886 r., Konwencję berneńska o ochronie dziet literackich $i$ artystycznych. Zakres pojęcia 'własność przemysłowa' w Konwencji paryskiej obejmuje wytwory myśli ludzkiej, czyli wynalazki, wzory użytkowe, wzory i modele przemysłowe, oznaczenia stosowane w handlu, tj. znaki towarowe i usługowe, nazwy handlowe, nazwy i oznaczenia pochodzenia towarów oraz zwalczanie nieuczciwej konkurencji. Własność przemysłowa i prawo autorskie tworzą własność intelektualną, która została po raz pierwszy określona w art. 2 Konwencji o ustanowieniu Światowej Organizacji Własności Intelektualnej (WIPO /OMPI), przyjętej 14 lipca 1967 r. Zakres tego pojęcia obejmuje prawa odnoszące się do dzieł literackich, artystycznych i naukowych, interpretacji artystów interpretatorów oraz do wykonań artystów wykonawców, do fonogramów i do programów radiowych i telewizyjnych, wynalazków we wszystkich dziedzinach działalności ludzkiej, odkryć naukowych, wzorów przemysłowych, znaków towarowych i usługowych, jak również do nazw handlowych i oznaczeń handlowych, ochrony przed nieuczciwą konkurencją oraz wszelkie inne prawa dotyczące działalności intelektualnej w dziedzinie przemysłowej, naukowej, literackiej i artystycznej (art. 2).

W kolejnych dekadach XX w. następowały zmiany w obszarze prawa własności intelektualnej w kierunku wypracowania lepszych standardów dotyczących dostępności, zakresu 
i korzystania z tych praw, także odpowiednich procedur opartych na zasadzie słuszności i sprawiedliwości w odniesieniu do ich dochodzenia i egzekwowania. Znalazło to odzwierciedlenie w Porozumieniu $w$ sprawie handlowych aspektów praw własności intelektualnej (TRIPS), stanowiącym jeden z załączników do Porozumienia ustanawiającego Światową Organizację Handlu (WTO), sporządzonego w Marakeszu 15 kwietnia 1994 r. Większa część przepisów TRIPS dotyczy własności przemysłowej, wprowadzając nowy przedmiot ochrony - topografie układów scalonych, a ponadto postanowienia dotyczące ochrony nieujawnionej informacji. Zgodnie $\mathrm{z}$ art. 7 określającym cele TRIPS

ochrona oraz dochodzenie i egzekwowanie praw własności intelektualnej powinny przyczynić się do promocji innowacji technicznych oraz do transferu i upowszechniania technologii, ze wzajemną korzyścią dla producentów i użytkowników wiedzy technicznej, w sposób sprzyjający osiągnięciu dobrobytu społecznego i gospodarczego oraz zrównoważeniu praw i obowiązków (Porozumienie, 1994).

W świecie dynamicznego rozwoju technologii informacyjno-komunikacyjnych, przede wszystkim poprzez Internet, towary, technologia oraz treści kreatywne mogą docierać do szerszego grona odbiorców, a twórcy, innowatorzy mogą szybciej wprowadzać nowe i innowacyjne rozwiązania. To wymaga działań na rzecz lepszego, skuteczniejszego systemu egzekwowania prawa własności intelektualnej, pomagającego chronić własność intelektualną i zapobiegającego naruszeniom tych praw. Tego rodzaju działania widoczne są na poziomie Unii Europejskiej, mianowicie Komisja wraz z Urzędem UE ds. Własności Intelektualnej (EUIPO) będzie działać razem z państwami członkowskimi w kierunku dalszego zwiększania świadomości społeczeństwa w odniesieniu do roli własności intelektualnej oraz negatywnych skutków naruszeń własności intelektualnej (Komunikat KE, 2017b).

Wiedza z zakresu ochrony własności intelektualnej w środowisku zaawansowanych technologii informacyjno-komunikacyjnych, w kontekście postępującej digitalizacji gospodarki powinna być istotnym elementem kształcenia na poziomie akademickim charakteryzującego się kreatywnością podejścia do edukacji. Studenci stanowią bardzo ważną grupę odbiorców tego rodzaju wiedzy, gdyż kluczowe znaczenie ma przygotowanie do życia w zglobalizowanym świecie, do uczestniczenia w globalnej gospodarce, która coraz bardziej zależy od własności intelektualnej (Soetendorp et al., 2016; Willinsky, 2017).

\section{Uwarunkowania nauczania w zakresie własności intelektualnej w uczelniach polskich}

Początki ochrony własności intelektualnej w Polsce wiążą się z powołaniem Urzędu Patentowego na mocy dekretu tymczasowego Naczelnika Państwa z 18 grudnia 1918 r. W 1919 r. Polska przystąpiła do Międzynarodowego Związku Ochrony Własności Przemysłowej (Oświadczenie, 1922) ${ }^{1}$, a w 1920 r. - do Konwencji berneńskiej o ochronie dziet literackich $i$ artystycznych. W 1919 r. wydano trzy dekrety Naczelnika Państwa dotyczące

1 Polska, wykonując postanowienia art. 19 aneksu I Traktatu między Głównymi Mocarstwami sprzymierzonymi i stowarzyszonymi a Polską, podpisanego w Wersalu 28 czerwca 1919 r. (Dz.U. 1920 Nr 110 poz. 728), zobowiązała się przystąpić w ciągu 12 miesięcy od dnia zawarcia Traktatu do międzynarodowych Konwencji wyszczególnionych w aneksie I, w tym do Konwencji Paryskiej o ochronie własności przemysłowej z 20 marca 1883 r. Oświadczenie Rządowe o przystąpieniu Polski do Międzynarodowego Związku Ochrony Własności Przemysłowej zostało wydane w 1922 r. 
patentów na wynalazki (Dekret, 1919c), ochrony wzorów rysunkowych i modeli (Dekret, 1919a) oraz ochrony znaków towarowych (Dekret, 1919b), następnie uchylone ustawą z 5 lutego 1924 r. o ochronie wynalazków, wzorów i znaków towarowych (Ustawa, 1924). W 1928 r. Prezydent RP wydał rozporządzenie z mocą ustawy o ochronie wynalazków, wzorów i znaków towarowych (Rozporządzenie, 1928), które uchyliło wcześniejszą ustawę. Należy przypomnieć, że uchwalono także ustawę o zwalczaniu nieuczciwej konkurencji (Ustawa, 1926b).

Oprócz wymienionych aktów normatywnych dotyczących własności przemysłowej, regulacją objęto także dziedzinę praw na dobrach niematerialnych, przyjmując 29 marca 1926 r. ustawę o prawie autorskim (Ustawa, 1926a).

W okresie międzywojennym podkreślano, że

(...) wyższe uczelnie powinny być ośrodkami nauczania i sposobienia do praktycznej działalności [...], prowadzenia badań naukowo-twórczych i doskonalenia wiedzy technicznej (...) (Świętosławski, $1927,6)$.

Ustawa o Szkołach Akademickich z 1933 r. (Ustawa, 1933) wskazywała w art. 1 na zadania w odniesieniu do prowadzenia badawczej i twórczej pracy naukowej, wdrażania do samodzielnych badań naukowych, także przygotowania do wykonywania zawodów wymagających naukowego opanowania danej gałęzi wiedzy.

Po II wojnie światowej, w okresie PRL, od lat 70. większość uczelni technicznych uwzględniała w programach kształcenia wybrane treści, przede wszystkim z zakresu ochrony własności przemysłowej. Było to związane także z przyjętymi w tamtym czasie rozwiązaniami prawnymi w odniesieniu do rozwoju działalności informacyjnej w obszarze informacji naukowej, technicznej, ekonomicznej i jej efektywnego wykorzystywania w gospodarce narodowej, w tym informacji o osiągnięciach nauki, techniki, ekonomiki, informacji o zarządzaniu oraz informacji patentowej (Uchwała RM, 1971).

Rozpad dotychczasowego systemu politycznego i gospodarczego oraz głęboka restrukturyzacja w kierunku gospodarki rynkowej na początku lat 90. XX w. otwierały nowe możliwości kształtowania systemu nauki polskiej i systemu edukacji narodowej, w tym określenia nowoczesnych standardów nauczania w odniesieniu do różnych kierunków studiów. Widoczne od początku transformacji ustrojowo-gospodarczej w Polsce starania podejmowane w celu upowszechniania wiedzy z zakresu własności intelektualnej w szkołach wyższych nie przyniosły oczekiwanych efektów. Powołana w 1989 r. Rada Rzeczników Patentowych Szkół Wyższych przyjęła jako jeden z priorytetów działania sprawy kształcenia studentów w dziedzinie własności intelektualnej, postulując włączenie wykładów z tego zakresu do minimów programowych. W rezultacie w lat 1997-1998 w porozumieniu z ówczesnymi instytucjami nauki i szkolnictwa wyższego powołano zespół, który przygotował propozycje ramowych programów nauczania przedmiotu Ochrona własności intelektualnej dla różnych typów szkół wyższych i różnych rodzajów studiów.

Środowisko akademickie reprezentowane m.in. przez takie gremia jak Konferencja Rektorów Polskich Uczelni Technicznych (KRPUT), Konferencja Rektorów Akademickich Szkół Polskich (KRASP), Rada Główna Nauki i Szkolnictwa Wyższego (RGNiSW) podejmowało działania mające na celu wypracowanie odpowiednich aktów normatywnych, wprowadzających zajęcia z zakresu ochrony własności intelektualnej do programów kształcenia w szkołach wyższych. Przykładem może być posiedzenie plenarne RGNiSW z 15 lipca 
2004 r., na którym dyskutowano wokół dwóch głównych tematów, tj. kierunków studiów oraz standardów kształcenia. Jak wskazuje protokół z tego posiedzenia, Prezes Urzędu Patentowego RP, Alicja Adamczak apelowała o wprowadzenie do standardów nauczania przedmiotu obejmującego problemy zasad ochrony własności intelektualnej:

Wprowadzenie tych zagadnień [...] na każdym kierunku studiów, ze zróżnicowaniem programu, uwzględniającym specyfikę kierunku studiów, przyniosłoby wymierne efekty w postaci, np. ograniczenia liczby plagiatów dokonywanych przez studentów czy też zabezpieczenia w przyszłości rezultatów ich twórczej pracy (Protokół RGNiSW, 2004).

W tym kontekście należy przypomnieć wypowiedź z 2007 r. prof. Michała du Valla na temat wprowadzenia standardów nauczania własności intelektualnej, który, dzieląc się doświadczeniami w tym obszarze Instytutu Prawa Własności Intelektualnej Uniwersytetu Jagiellońskiego, stwierdził:

\footnotetext{
Nauczanie nie jest powszechne i panuje w tym zakresie asymetria, na niektórych wydziałach edukacja z zakresu własności intelektualnej jest dobrze rozwinięta, na innych - w ogóle nieobecna. Nie ma jednolitego programu (czyli ustalonych standardów) (Vall, 2007, 3-4).
}

\section{Ochrona własności intelektualnej w standardach kształcenia studentów}

Po 1989 r., od początku transformacji ustrojowej przystąpiono do reformy nauki i szkolnictwa wyższego, w tym określenia w drodze rozporządzeń standardów nauczania dla poszczególnych kierunków studiów i poziomów kształcenia z uwzględnieniem ramowych treści nauczania dla danych przedmiotów (ogólnych, podstawowych, kierunkowych). W ciągu prawie 30 lat przyjęto następujące akty normatywne kluczowe dla standardów nauczania:

- Ustawa z dnia 12 września 1990 r. o szkolnictwie wyższym [Dz.U. 1990, Nr 65, poz. 385] (Ustawa, 1990)

- Rozporządzenie Ministra Edukacji Narodowej i Sportu z dnia 18 kwietnia 2002 r. w sprawie określenia standardów nauczania dla poszczególnych kierunków studiów i poziomów kształcenia [Dz.U. 2002, Nr 116, poz. 1004] (Rozporządzenie MENiS, 2002)

- Rozporządzenie Ministra Edukacji Narodowej i Sportu z dnia 13 czerwca 2003 r. zmieniające rozporządzenie w sprawie określenia standardów nauczania dla poszczególnych kierunków studiów i poziomów kształcenia [Dz.U. 2003, Nr 144, poz. 1401] (Rozporządzenie MENiS, 2003)

- Ustawa z dnia 27 lipca 2005 r. Prawo o szkolnictwie wyższym [Dz.U. 2005, Nr 164, poz. 1365] (Ustawa, 2005)

- Rozporządzenie Ministra Nauki i Szkolnictwa Wyższego z dnia 12 lipca 2007 r. w sprawie standardów kształcenia dla poszczególnych kierunków oraz poziomów kształcenia, a także trybu tworzenia i warunków, jakie musi spełniać uczelnia, by prowadzić studia międzykierunkowe oraz makrokierunki [Dz.U. 2007, Nr 164, poz. 1166] (Rozporządzenie MNiSW, 2007)

- Rozporządzenie Ministra Nauki i Szkolnictwa Wyższego z dnia 2 listopada 2011 r. w sprawie Krajowych Ram Kwalifikacji dla Szkolnictwa Wyższego [Dz.U. 2011, Nr 253, poz. 1520], (Rozporządzenie MNiSW, 2011) 
- Ustawa z dnia 22 grudnia 2015 r. o Zintegrowanym Systemie Kwalifikacji [Dz.U. 2016, poz. 64] (Ustawa, 2016)

- Rozporządzenie Ministra Nauki i Szkolnictwa Wyższego z dnia 26 września 2016 r. w sprawie charakterystyk drugiego stopnia Polskiej Ramy Kwalifikacji typowych dla kwalifikacji uzyskiwanych w ramach szkolnictwa wyższego po uzyskaniu kwalifikacji pełnej na poziomie 4 - poziomy 6-8 [Dz.U. 2016, poz. 1594 - uchylone (Rozporządzenie MNiSW, 2016)

- Ustawa z dnia 3 lipca 2018 r. - Przepisy wprowadzające ustawę - Prawo o szkolnictwie wyższym i nauce [Dz.U. 2018, poz. 1669] (Ustawa, 2018a)

- Ustawa z dnia 20 lipca 2018 r. - Prawo o szkolnictwie wyższym i nauce [Dz.U. 2018, poz. 1668] (Ustawa, 2018b)

- Rozporządzenie Ministra Nauki i Szkolnictwa Wyższego z dnia 14 listopada 2018 r. w sprawie charakterystyk drugiego stopnia efektów uczenia się dla kwalifikacji na poziomach 6-8 Polskiej Ramy Kwalifikacji [Dz.U. 2018, poz. 2218] (Rozporządzenie MNiSW, 2018c).

Standardy nauczania regulowane rozporządzeniem MENiS z 2002 r. wskazywały w zależności od zainteresowania studenta - na możliwości (nie obligatoryjność) uzyskania szerszej wiedzy z zakresu ochrony własności intelektualnej czy własności przemysłowej. Kolejne rozporządzenie MNiSW z 2007 r. zobowiązywało uczelnie do zapewnienia wysokiej jakości kształcenia i utworzenia wewnętrznego systemu zapewnienia jakości. Standardy kształcenia zawarte w załącznikach do rozporządzenia w ramach innych wymagań określały w odniesieniu do niemal wszystkich studiów pierwszego stopnia, że programy nauczania powinny zawierać treści („powinny przewidywać zajęcia” lub „powinny obejmować treści”) z zakresu ochrony własności intelektualnej. Należy zauważyć, że dla niektórych kierunków studiów przewidywano już na pierwszym stopniu rozszerzenie zagadnień własności intelektualnej, (np. na kierunku informatyka w obszarze kształcenia w zakresie problemów społecznych i zawodowych informatyki treści obejmowały problemy i zagadnienia prawne dotyczące własności intelektualnej, system patentowy i prawne podstawy ochrony prywatności), a także w ramach studiów drugiego stopnia, np. biotechnologii, farmacji czy informacji naukowej i bibliotekoznawstwa.

Przeprowadzona w 2011 r. nowelizacja Ustawy Prawo o szkolnictwie wyższym wprowadziła pojęcie „Krajowe Ramy Kwalifikacji dla Szkolnictwa Wyższego”, tj. opis nauczanych treści przez określenie efektów kształcenia, kwalifikacji zdobywanych w polskim systemie szkolnictwa wyższego, zdefiniowała kwalifikacje pierwszego stopnia, drugiego stopnia i trzeciego stopnia, odpowiadające efektom kształcenia na studiach pierwszego stopnia (licencjackich), drugiego stopnia (magisterskich) oraz trzeciego stopnia (doktoranckich). W rezultacie w drodze aktu wykonawczego, czyli rozporządzenia MNiSW z 2 listopada 2011 r. w sprawie Krajowych Ram Kwalifikacji dla Szkolnictwa Wyższego opisano efekty kształcenia dla profilu ogólnoakademickiego oraz dla profilu praktycznego w obszarze kształcenia nauk humanistycznych, nauk społecznych, ścisłych, przyrodniczych, technicznych, medycznych, rolniczych i sztuki, włączając także wiedzę z zakresu własności intelektualnej do oczekiwanych efektów kształcenia.

W 2015 r. przyjęto ustawę o Zintegrowanym Systemie Kwalifikacji ustanawiającej Polską Ramę Kwalifikacji (Ustawa, 2016), tj. opis ośmiu wyodrębnionych w Polsce poziomów kwalifikacji odpowiadających poziomom europejskich ram kwalifikacji (art. 2 pkt 16), a w 2016 r. 
w drodze rozporządzenia do ustawy (uchylone 1 października 2018 r.) określono charakterystyki poziomów 6-8 drugiego stopnia typowe dla kwalifikacji uzyskiwanych w ramach systemu szkolnictwa wyższego, ujęte w kategoriach wiedzy, umiejętności i kompetencji społecznych (Rozporządzenie, 2016). Efekty uczenia się wspólne dla obszarów kształcenia obejmowały w kategorii wiedzy znajomość i rozumienie przez studenta podstawowych pojęć i zasad z zakresu ochrony własności przemysłowej i prawa autorskiego (poziom 6-7). Nieobowiązujące dziś rozporządzenie określało także charakterystyki efektów kształcenia dla poszczególnych obszarów kształcenia, np. w obszarze kształcenia w zakresie nauk humanistycznych i nauk społecznych w kategorii wiedza - absolwent zna i rozumie zasady ochrony własności przemysłowej i prawa autorskiego (poziom 6), zasady zarządzania zasobami własności intelektualnej (poziom 7).

W związku z przyjęciem w lipcu 2018 r. nowej ustawy - Prawo o szkolnictwie wyższym i nauce (Ustawa, 2018b) oraz przepisów ją wprowadzających, MNiSW przygotowało rozporządzenie (Rozporządzenie, 2018b; Rozporządzenie, 2018c), które wprawdzie utrzymuje - występującą w poprzednio obowiązującym rozporządzeniu z 2016 r. - trójdzielną konstrukcję opisu charakterystyk drugiego stopnia efektów uczenia się dla kwalifikacji na poziomach 6-8 PRK, rezygnuje jednak z uszczegóławiania opisów charakterystyk z uwzględnieniem obszarów kształcenia (pozostawiając jedynie w odniesieniu do dziedziny sztuki). W dokumencie MNiSW oceniającym skutki projektowanej regulacji czytamy:

(...) zmiana treści upoważnienia ustawowego polega na dostosowaniu do nowej terminologii („system szkolnictwa wyższego i nauki”). Jednak [...] zmiany wprowadzone ustawą skutkują nie tylko koniecznością dostosowania przedmiotowego rozporządzenia pod kątem terminologicznym, ale również pod kątem zmian w systemie szkolnictwa wyższego i nauki (np. w nowej dwustopniowej klasyfikacji dziedzin nauki i dyscyplin naukowych [...] nie przewiduje się podziału na obszary wiedzy, które były podstawą obecnej trzystopniowej klasyfikacji) (Rozporządzenie, 2018a, 1).

Ponadto, rozporządzenie wprowadza uzupełnienie opisu charakterystyk dla efektów uczenia się na kierunkach studiów o profilu ogólnoakademickim i o profilu praktycznym o następujące kategorie opisowe:

- zakres i głębia wiedzy - kompletność perspektywy poznawczej i zależności,

- kontekst wiedzy - uwarunkowania, skutki,

- wykorzystanie wiedzy - rozwiązywane problemy i wykonywane zadania.

W odniesieniu do własności intelektualnej w rozporządzeniu określono, że absolwent studiów (poziom 6-7) - w zakresie wiedzy - zna i rozumie

(...) podstawowe ekonomiczne, prawne, etyczne i inne uwarunkowania różnych rodzajów działalności zawodowej związanej z kierunkiem studiów, w tym podstawowe pojęcia i zasady z zakresu ochrony własności przemysłowej i prawa autorskiego,

absolwent studiów doktoranckich (poziom 8)

(...) - podstawowe zasady transferu wiedzy do sfery gospodarczej i społecznej oraz komercjalizacji wyników działalności naukowej i know-how związanego z tymi wynikami (Załącznik, 2018, 2). 


\section{Ochrona własności intelektualnej w programach kształcenia studentów zarządzania informacją i kierunków pokrewnych}

Kształcenie akademickie profesjonalistów informacji (najpierw specjalistów informacji naukowej, później także specjalistów zarządzania informacją i architektów informacji) w systemowej formie studiów magisterskich rozpoczęło się w Polsce wraz z powołaniem w 1974 r. kierunku studiów Bibliotekoznawstwo i informacja naukowa i jego realizacją na Uniwersytecie Jagiellońskim, Uniwersytecie Adama Mickiewicza w Poznaniu, Uniwersytecie Warszawskim i Uniwersytecie Wrocławskim, następnie na Uniwersytecie Łódzkim, Uniwersytecie Marii Curie-Skłodowskiej, Uniwersytecie Śląskim, Uniwersytecie Mikołaja Kopernika w Toruniu, w Wyższej Szkole Pedagogicznej w Krakowie (obecnie Uniwersytet Pedagogiczny im. KEN). Na przestrzeni kilkudziesięciu lat nastąpiły zmiany w odniesieniu do doskonalenia uniwersyteckiej dydaktyki w zakresie informacji naukowej i bibliotekoznawstwa, w tym zmiany dotyczące organizacji studiów, programów kształcenia czy standardów jakości procesu edukacyjnego. Wiedza z zakresu ochrony własności intelektualnej stała się istotnym efektem kształcenia.

Standardy nauczania dla kierunku informacja naukowa i bibliotekoznawstwo, uchylone w 2007 r., określały obok grupy przedmiotów podstawowych i kierunkowych (m.in. naukoznawstwo, komunikacja społeczna, technologia informacyjna, nauka o informacji) przedmioty kształcenia ogólnego (m.in. historia filozofii, historia i teoria kultury), a wśród nich przedmiot do wyboru (m.in. podstawy ochrony własności intelektualnej) w wymiarze 30 godzin:

(...) w zależności od zainteresowań studenta możliwość uzyskania szerszej wiedzy z zakresu historii, podstaw ochrony własności intelektualnej, przedmiotu przyrodniczego lub innego przedmiotu niezwiązanego bezpośrednio z kierunkiem studiów (Załączniki, 2003, 9706).

Kolejne standardy kształcenia dla poszczególnych kierunków oraz poziomów kształcenia z 2007 r., uwzględniając tendencje i charakter zmian w obszarze edukacji na poziomie wyższym, jak również w sferze badań naukowych w Europie, określane mianem Procesu Bolońskiego i Strategii Lizbońskiej, także przemiany społeczno-gospodarcze, dla kierunku studiów informacji naukowej i bibliotekoznawstwa na pierwszym poziomie kształcenia, treści kierunkowe w ramach kształcenia dotyczącego zagadnień wydawniczych obejmowały także prawo autorskie. Ówczesne MNiSW rekomendowało również w obszarze innych wymagań, że programy nauczania powinny przewidywać zajęcia z zakresu ochrony własności intelektualnej. Standardy kształcenia na studiach drugiego stopnia informacji naukowej i bibliotekoznawstwa zakładały m.in., że

(...) absolwent studiów powinien posiadać rozszerzoną wiedzę z zakresu informacji naukowej i bibliotekoznawstwa [...], powinien być przygotowany do rozwoju własnej kariery zawodowej związanej z kierowaniem i zarządzaniem w instytucjach bibliotecznych oraz ośrodkach i oddziałach informacji, kierowania przedsięwzięciami w zakresie informacji elektronicznej; organizowania i prowadzenia działalności naukowo-badawczej w dziedzinie informacji naukowej (...) (Rozporządzenie MNiSW, 2007, zał. 44, 328).

Dlatego też, treści kierunkowe kształcenia w zakresie problematyki prawnej w działalności informacyjnej i bibliotecznej uwzględniały prawo autorskie, prawo patentowe, stanowiące części należące do dziedziny własności intelektualnej. 
Kolejne dokumenty, omawiane wcześniej, mianowicie rozporządzenie z 2011 r. opisujące efekty kształcenia w związku z wprowadzeniem Krajowych Ram Kwalifikacji dla Szkolnictwa Wyższego, jak również rozporządzenie z 2016 r., obejmowały także wiedzę z zakresu ochrony własności intelektualnej. Odpowiednio, ostatni dokument z listopada 2018 r., opracowany w związku z nową ustawą Prawo o szkolnictwie wyższym wskazuje na efekty kształcenia w kategorii wiedzy na zagadnienia ochrony własności przemysłowej i prawa autorskiego.

W badaniach, których wyniki zostały omówione w niniejszym artykule, analizą objęto 10 publicznych uczelni akademickich - uniwersytetów, które prowadzą 12 kierunków studiów kształcących profesjonalistów informacji w szerokim tego słowa znaczeniu - specjalistów zarządzania informacją, bibliotekoznawców, brokerów informacji, architektów informacji czy specjalistów działalności wydawniczej i specjalistów zarządzania dokumentacją. Szczegółowe dane zawarto w tabeli 1, w której w kolumnie pierwszej widoczne są nazwy kierunków studiów, a w kolumnie trzeciej - nazwy przedmiotów realizowanych na poszczególnych kierunkach; środkowa część tabeli zawiera w nagłówkach skróty nazw uniwersytetów, na których występują wymienione kierunki.

Z przeprowadzonych badań wynika, że zajęcia dotyczące problematyki ochrony własności intelektualnej oraz zagadnień z nią związanych są prowadzone na 10 kierunkach studiów, mianowicie:

- Architektura informacji

- Architektura przestrzeni informacyjnych

- Informacja naukowa i bibliotekoznawstwo

- Informacja w instytucjach e-społeczeństwa

- Informacja w środowisku cyfrowym

- Publikowanie cyfrowe i sieciowe

- Publikowanie współczesne

- Zarządzanie informacją

- Zarządzanie informacją i bibliologia

- Zarządzanie informacją i publikowanie cyfrowe.

W programie kształcenia na kierunkach Informatologia stosowana oraz Informatologia z biznesowym językiem angielskim nie przewidziano przedmiotu w odniesieniu do problematyki ochrony własności intelektualnej, w tym prawa autorskiego.

Należy zauważyć, że oferowane przedmioty różnią się nazwą, a także zakresem kształcenia, typem i liczbą godzin realizowanych zajęć, formą i warunkami zaliczenia czy też rokiem studiów, na którym przedmiot jest wykładany.

Z badań wynika, że najczęstszą nazwą przedmiotu jest „Ochrona własności intelektualnej”, występująca na sześciu kierunkach kształcących profesjonalistów informacji (Architektura informacji; Informacja naukowa i bibliotekoznawstwo; Publikowanie współczesne; Zarządzanie informacją; Zarządzanie informacją i bibliologia; Zarządzanie informacją i publikowanie cyfrowe), ponadto, „Podstawy ochrony własności intelektualnej” (na kierunku Architektura przestrzeni informacyjnych), „Ochrona własności intelektualnej i przemysłowej" (na kierunku Informacja w instytucjach e-społeczeństwa). Niektóre programy studiów obejmują także odrębne przedmioty dotyczące prawa autorskiego w związku z działalnością biblioteczną, informacyjną i wydawniczą (na kierunkach Informacja naukowa i bibliotekoznawstwo, Informacja w środowisku cyfrowym, Publikowanie cyfrowe i sieciowe, 
Publikowanie współczesne). Większość przedmiotów ma status obligatoryjny do zaliczenia danego semestru / roku studiów, kilka - status fakultatywny, do wyboru lub obowiązkowy w ramach danej specjalizacji, np. „Prawo konkurencji” na kierunku Architektura informacji na Uniwersytecie Pedagogicznym w Krakowie, „Prawne aspekty reklamy / prawo patentowe” na kierunku Publikowanie cyfrowe i sieciowe na Uniwersytecie Wrocławskim czy „Prawne aspekty publikowania w Internecie” na studiach II stopnia na kierunku Informacja naukowa i bibliotekoznawstwo na Uniwersytecie Śląskim w Katowicach. Przedmioty są realizowane przeważnie w formie wykładów, sporadycznie w formie konwersatoriów („Prawo autorskie” na kierunku Informacja naukowa i bibliotekoznawstwo na Uniwersytecie Wrocławskim; „Historia prawa autorskiego”, jak również „Prawo patentowe” na kierunku Publikowanie cyfrowe i sieciowe na Uniwersytecie Wrocławskim), ćwiczeń („Ochrona własności intelektualnej” na kierunkach Architektura informacji oraz Zarządzanie informacją i bibliologia na Uniwersytecie Mikołaja Kopernika w Toruniu). Zauważalne są różnice w odniesieniu do liczby godzin, od wykładów 30-godzinnych w zakresie ochrony własności intelektualnej, prowadzonych na kierunku Zarządzanie informacją na Uniwersytecie Jagiellońskim, także na studiach Informacji naukowej i bibliotekoznawstwa Uniwersytetu Śląskiego, wykładów 20-godzinnych z prawa autorskiego w pracy wydawcy na kierunku Publikowanie cyfrowe i sieciowe na Uniwersytecie Wrocławskim, przeważających 15-godzinnych wykładów (np. „Prawne aspekty publikowania w Internecie”; „Ochrona własności intelektualnej i przemysłowej”; „Prawo i etyka w działalności wydawniczej i informacyjnej”) po 4-godzinne wykłady na kierunkach Architektura informacji, Informacja naukowa i bibliotekoznawstwo oraz Publikowanie współczesne na Uniwersytecie Warszawskim. Programy kształcenia przewidują formę zaliczenia od egzaminu po zaliczenie na ocenę.

Tab. 1. Przedmioty z zakresu ochrony własności intelektualnej realizowane na kierunkach studiów związanych z zarządzaniem informacją i pokrewnych.

Na podstawie danych z systemu informacji o szkolnictwie wyższym POL-on oraz stron internetowych poszczególnych uniwersytetów. Stan na dzień 25.10.2018 r.

\begin{tabular}{|c|c|c|c|c|c|c|c|c|c|c|c|}
\hline \multirow[b]{2}{*}{$\begin{array}{c}\text { Nazwa } \\
\text { kierunku studiów }\end{array}$} & \multicolumn{10}{|c|}{ Uniwersytety } & \multirow[b]{2}{*}{$\begin{array}{l}\text { Przedmioty z zakresu ochrony } \\
\text { własności intelektualnej } \\
\text { realizowane na poszczególnych } \\
\text { kierunkach studiów }\end{array}$} \\
\hline & 5 & 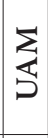 & 5 & 呫 & $\sum_{i}^{\infty}$ & $\sum_{S}$ & 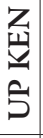 & s & 5 & $\frac{3}{5}$ & \\
\hline 1 & 2 & 3 & 4 & 5 & 6 & 7 & 8 & 9 & 10 & 11 & 12 \\
\hline \multirow{3}{*}{$\begin{array}{l}\text { Architektura } \\
\text { informacji }\end{array}$} & & & & & - & - & - & - & & & \\
\hline & & & & & $\checkmark$ & $\checkmark$ & $\checkmark$ & $\checkmark$ & & & $\begin{array}{l}\text { Ochrona własności intelektualnej } \\
\text { (studia I stopnia) }\end{array}$ \\
\hline & & & & & & & $\checkmark$ & & & & $\begin{array}{l}\text { Prawo konkurencji } \\
\text { (w ramach kursów do wyboru, studia I stopnia) }\end{array}$ \\
\hline \multirow{2}{*}{$\begin{array}{l}\text { Architektura } \\
\text { przestrzeni } \\
\text { informacyjnych }\end{array}$} & - & & & & & & & & & & \\
\hline & $\checkmark$ & & & & & & & & & & $\begin{array}{l}\text { Podstawy ochrony własności intelektu- } \\
\text { alnej (studia I stopnia) }\end{array}$ \\
\hline
\end{tabular}




\begin{tabular}{|c|c|c|c|c|c|c|c|c|c|c|c|}
\hline 1 & 2 & 3 & 4 & 5 & 6 & 7 & 8 & 9 & 10 & 11 & 12 \\
\hline \multirow{6}{*}{$\begin{array}{l}\text { Informacja nauko- } \\
\text { wa i biblioteko- } \\
\text { znawstwo }\end{array}$} & - & - & & & & & - & - & - & - & \\
\hline & $\checkmark$ & $\checkmark$ & & & & & $\checkmark$ & $\checkmark$ & & & $\begin{array}{l}\text { Ochrona własności intelektualnej } \\
\text { (studia I stopnia) }\end{array}$ \\
\hline & & & & & & & & & & $\checkmark$ & $\begin{array}{l}\text { Ochrona własności intelektualnej, BHP } \\
\text { i ergonomia (studia I stopnia) }\end{array}$ \\
\hline & $\checkmark$ & & & & & & & & & & $\begin{array}{l}\text { Podstawy prawa autorskiego w dzia- } \\
\text { łalności bibliotecznej i informacyjnej } \\
\text { (I stopień) }\end{array}$ \\
\hline & & & & & & & & $\checkmark$ & & & $\begin{array}{l}\text { Prawne aspekty publikowania w Inter- } \\
\text { necie (studia II stopnia, w ramach specjalizacji) }\end{array}$ \\
\hline & & & & & & & & & $\checkmark$ & & Prawo autorskie (studia II stopnia) \\
\hline \multirow{2}{*}{$\begin{array}{l}\text { Informacja } \\
\text { w instytucjach } \\
\text { e-społeczeństwa }\end{array}$} & & & & & & & & - & & & \\
\hline & & & & & & & & $\checkmark$ & & & $\begin{array}{l}\text { Ochrona własności intelektualnej } \\
\text { i przemysłowej (studia I stopnia) }\end{array}$ \\
\hline \multirow{2}{*}{$\begin{array}{l}\text { Informacja w śro- } \\
\text { dowisku cyfrowym }\end{array}$} & & & & - & & & & & & & \\
\hline & & & & $\checkmark$ & & & & & & & $\begin{array}{l}\text { Prawo i etyka w działalności wydawni- } \\
\text { czej i informacyjnej (studia I stopnia) }\end{array}$ \\
\hline $\begin{array}{l}\text { Informatologia } \\
\text { stosowana }\end{array}$ & & & & & - & & & & & & \\
\hline $\begin{array}{l}\text { Informatologia } \\
\text { z biznesowym ję- } \\
\text { zykiem angielskim }\end{array}$ & & & & - & & & & & & & \\
\hline \multirow{5}{*}{$\begin{array}{l}\text { Publikowanie } \\
\text { cyfrowe i sieciowe }\end{array}$} & & & & & & & & & - & & \\
\hline & & & & & & & & & $\checkmark$ & & $\begin{array}{l}\text { Historia prawa autorskiego / Praktycz- } \\
\text { ne aspekty prawa (studia I stopnia) }\end{array}$ \\
\hline & & & & & & & & & $\checkmark$ & & $\begin{array}{l}\text { Prawne aspekty reklamy / Prawo paten- } \\
\text { towe (do wyboru; studia II stopnia niestacjonarne) }\end{array}$ \\
\hline & & & & & & & & & $\checkmark$ & & $\begin{array}{l}\text { Prawo autorskie w pracy wydawcy } \\
\text { (studia I stopnia) }\end{array}$ \\
\hline & & & & & & & & & $\checkmark$ & & $\begin{array}{l}\text { Prawo autorskie w praktyce wydawni- } \\
\text { czej (studia II stopnia niestacjonarne) }\end{array}$ \\
\hline \multirow{3}{*}{$\begin{array}{l}\text { Publikowanie } \\
\text { współczesne }\end{array}$} & & & & & & & & & & & \\
\hline & & & & & & & & & & & $\begin{array}{l}\text { Ochrona własności intelektualnej } \\
\text { (studia I stopnia) }\end{array}$ \\
\hline & & & & & & & & & & & $\begin{array}{l}\text { Aspekty prawne działalności wydawni- } \\
\text { czej (studia I stopnia) }\end{array}$ \\
\hline \multirow{4}{*}{$\begin{array}{l}\text { Zarządzanie } \\
\text { informacją }\end{array}$} & & & & & & & & & & & \\
\hline & & & & & & & & & & & $\begin{array}{l}\text { Ochrona własności intelektualnej } \\
\text { (studia I stopnia) }\end{array}$ \\
\hline & & & & & & & & & & & $\begin{array}{l}\text { Podstawy prawne zarządzanie informa- } \\
\text { cją (studia II stopnia) }\end{array}$ \\
\hline & & & & & & & & & & & $\begin{array}{l}\text { Podstawy własności przemysłowej } \\
\text { (studia II stopnia w ramach wybranej specjalizacji) }\end{array}$ \\
\hline
\end{tabular}




\begin{tabular}{|c|c|c|c|c|c|c|c|c|c|c|c|c|}
\hline & 1 & 2 & 3 & 4 & 5 & 6 & 7 & 8 & 9 & 10 & 11 & 12 \\
\hline \multirow{2}{*}{\multicolumn{2}{|c|}{$\begin{array}{l}\text { Zarządzanie } \\
\text { informacją } \\
\text { i bibliologia }\end{array}$}} & & & & & & - & & & & & \\
\hline & & & & & & & $\checkmark$ & & & & & $\begin{array}{l}\text { Ochrona własności intelektualnej } \\
\text { (studia II stopnia) }\end{array}$ \\
\hline \multirow{2}{*}{\multicolumn{2}{|c|}{$\begin{array}{l}\text { Zarządzanie } \\
\text { informacją i publi- } \\
\text { kowanie cyfrowe }\end{array}$}} & & & & & & & - & & & & \\
\hline & & & & & & & & $\checkmark$ & & & & $\begin{array}{l}\text { Ochrona własności intelektualnej } \\
\text { (studia I i II stopnia, e-learning) }\end{array}$ \\
\hline UW & \multicolumn{12}{|c|}{ Uniwersytet Warszawski / Wydział Dziennikarstwa, Informacji i Bibliologii } \\
\hline UAM & \multicolumn{12}{|c|}{$\begin{array}{l}\text { Uniwersytet im. Adama Mickiewicza w Poznaniu / Wydział Pedagogiczno-A } \\
\text { w Kaliszu }\end{array}$} \\
\hline UJ & \multicolumn{12}{|c|}{ Uniwersytet Jagielloński w Krakowie / Wydz } \\
\hline UŁ & \multicolumn{12}{|c|}{ Uniwersytet Łódzki / Wydział Filologiczny } \\
\hline UMCS & \multicolumn{12}{|c|}{ Uniwersytet Marii Curie-Skłodowskiej w Lublinie / Wydział Humanistyczny } \\
\hline UMK & \multicolumn{12}{|c|}{ Uniwersytet Mikołaja Kopernika w Toruniu / Wydział Nauk Historycznych } \\
\hline UPKEN & \multicolumn{12}{|c|}{$\begin{array}{l}\text { Uniwersytet Pedagogiczny im. Komisji Edukacji Narodowej w Krakowie / Wydział } \\
\text { Filologiczny }\end{array}$} \\
\hline UŚ & \multicolumn{12}{|c|}{ Uniwersytet Śląski w Katowicach / Wydział Filologiczny } \\
\hline UWr & \multicolumn{12}{|c|}{ Uniwersytet Wrocławski / Wydział Filologiczny } \\
\hline UKW & \multicolumn{12}{|c|}{$\begin{array}{l}\text { Uniwersytet Kazimierza Wielkiego w Bydgoszczy / Wydział Administracji i Nauk Spo- } \\
\text { łecznych }\end{array}$} \\
\hline
\end{tabular}

Z badań wynika, że najczęstszą nazwą przedmiotu jest „Ochrona własności intelektualnej” występująca na sześciu kierunkach kształcących profesjonalistów informacji (Architektura informacji; Informacja naukowa i bibliotekoznawstwo; Publikowanie współczesne; Zarządzanie informacją; Zarządzanie informacją i bibliologia; Zarządzanie informacją i publikowanie cyfrowe), ponadto, „Podstawy ochrony własności intelektualnej” (na kierunku Architektura przestrzeni informacyjnych), „Ochrona własności intelektualnej i przemysłowej” (na kierunku Informacja w instytucjach e-społeczeństwa). Niektóre programy studiów obejmują także odrębne przedmioty dotyczące prawa autorskiego w związku z działalnością biblioteczną, informacyjną i wydawniczą (na kierunkach Informacja naukowa i bibliotekoznawstwo, Informacja w środowisku cyfrowym, Publikowanie cyfrowe i sieciowe, Publikowanie współczesne). Większość przedmiotów ma status obligatoryjny do zaliczenia danego semestru / roku studiów, kilka - status fakultatywny, do wyboru lub obowiązkowy w ramach danej specjalizacji, np. „Prawo konkurencji” na kierunku Architektura informacji na Uniwersytecie Pedagogicznym w Krakowie, „Prawne aspekty reklamy / prawo patentowe” na kierunku Publikowanie cyfrowe i sieciowe na Uniwersytecie Wrocławskim czy „Prawne aspekty publikowania w Internecie” na studiach II stopnia na kierunku Informacja naukowa i bibliotekoznawstwo na Uniwersytecie Śląskim w Katowicach. Przedmioty są realizowane przeważnie w formie wykładów, sporadycznie w formie konwersatoriów („Prawo autorskie” na kierunku Informacja naukowa i bibliotekoznawstwo na Uniwersytecie Wrocławskim; „Historia prawa autorskiego”, jak również „Prawo patentowe” na kierunku Publikowanie cyfrowe i sieciowe na Uniwersytecie Wrocławskim), ćwiczeń („Ochrona własności intelektualnej” na kierunkach Architektura informacji oraz Zarządzanie informacją i bibliologia na Uniwersytecie Mikołaja Kopernika w Toruniu). Zauważalne są różnice w odniesieniu do liczby godzin, od wykładów 30-godzinnych w zakresie ochrony własności intelektualnej, prowadzonych na kierunku Zarządzanie informacją na Uniwersytecie Jagiellońskim, także na studiach Informacji naukowej i bibliotekoznawstwa 
Uniwersytetu Śląskiego, wykładów 20-godzinnych z prawa autorskiego w pracy wydawcy na kierunku Publikowanie cyfrowe i sieciowe na Uniwersytecie Wrocławskim, przeważających 15-godzinnych wykładów (np. „Prawne aspekty publikowania w Internecie”; „Ochrona własności intelektualnej i przemysłowej”; „Prawo i etyka w działalności wydawniczej i informacyjnej") po 4-godzinne wykłady na kierunkach Architektura informacji, Informacja naukowa i bibliotekoznawstwo oraz Publikowanie współczesne na Uniwersytecie Warszawskim. Programy kształcenia przewidują formę zaliczenia od egzaminu po zaliczenie na ocenę.

\section{Ochrona własności intelektualnej w programie kształcenia na kierunku zarządzanie informacją na Uniwersytecie Jagiellońskim}

W dalszych rozważaniach posłużono się metodą case study, wybrano przykład kierunku studiów zarządzanie informacją, uruchomionego po raz pierwszy w roku akademickim 2014/2015 przez Instytut Informacji Naukowej i Bibliotekoznawstwa (obecnie Instytut Studiów Informacyjnych) na Wydziale Zarządzania i Komunikacji Społecznej Uniwersytetu Jagiellońskiego. Studia I i II stopnia w tym zakresie oferują nowoczesne i innowacyjne treści w wymiarze humanistycznym, społecznym i technicznym, które są powiązane z kształceniem umiejętności praktycznych, rozwijaniem i doskonaleniem pożądanych przez pracodawców kompetencji zawodowych związanych z profesją specjalisty zarządzania informacją, menedżera informacji, także brokera informacji, researchera, pracownika wywiadowni gospodarczych czy analityka informacji. W tym kontekście kształcenie z zakresu ochrony własności intelektualnej staje się niezbędne, mając na uwadze, że

(...) zarówno w kształceniu jak i w badaniach należy przyjąć podejście wielopłaszczyznowe do wiedzy, a w związku z tym [...] zarówno uczelnie jak i przedsiębiorstwa mogłyby skorzystać na wspólnym rozwijaniu umiejętności multi - i interdyscyplinarnych i przedsiębiorczości, elastycznie dostosowując kierunki studiów oraz specjalności i specjalizacje do potrzeb gospodarki, w tym małych i średnich przedsiębiorstw (Rezolucja PE, 2010, pkt 48).

Przyjęty w 2015 r. program kształcenia na kierunku Zarządzanie informacją na studiach stacjonarnych I stopnia o profilu ogólnoakademickim wskazuje ogólne cele kształcenia, m.in.:

- przygotowanie studenta do podejmowania naukowych działań poznawczych w odniesieniu do szerokiej grupy zjawisk i procesów, od tych warunkujących poszukiwanie informacji, poprzez jej pozyskiwanie, gromadzenie, opracowanie i przetwarzanie, do udostępniania i wykorzystania przez człowieka,

- przygotowanie do wykonywania zadań profesjonalnych w zakresie zarządzania informacją w różnych instytucjach i organizacjach funkcjonujących w obszarze komunikacji publicznej, kultury, edukacji, biznesu, nauki i administracji,

- wykształcenie absolwenta, który powinien być przygotowany do dalszego rozwijania swoich umiejętności badawczych na studiach wyższego poziomu, [...] powinien być profesjonalistą, który nie tylko potrafi sprawnie realizować zadania zawodowe i rozwiązywać problemy profesjonalne, ale również rozumie sens i najważniejsze uwarunkowania wykonywanej pracy oraz dostrzega jej historyczny, społeczny i kulturowy kontekst,

- studia mają umożliwić absolwentowi efektywne funkcjonowanie w środowisku akademickim i profesjonalnym, korzystać w sposób świadomy z dorobku kultury, 
szanując zasady prawa, uczestniczyć w różnorodnych formach współczesnego życia kulturalnego (UJ, b.d. e, 1-2).

Z kolei program kształcenia w zakresie zarządzania informacją na studiach stacjonarnych II stopnia w ramach ogólnych celów kształcenia przewiduje m.in., że absolwent

(...) jest również przygotowany do rozwiązywania nietypowych problemów, proponowania rozwiązań oryginalnych i innowacyjnych, pełnienia roli lidera w środowisku profesjonalnym (...) (UJ, b.d. f, 2).

Chodzi o przygotowanie wysokiej klasy specjalisty w wybranym obszarze związanym z zarządzaniem informacją, a szczególnie: bibliotekarstwem, infobrokerstwem i wywiadem gospodarczym, projektowaniem, tworzeniem i udostępnianiem kolekcji cyfrowych lub transferem wiedzy z nauki do gospodarki.

Odpowiednio do celów, w opisie zakładanych efektów kształcenia przyjęto, że absolwent studiów I i II stopnia zarządzania informacją w ramach wiedzy zna i rozumie podstawowe pojęcia, regulacje i zasady z zakresu ochrony własności intelektualnej i prawa autorskiego oraz identyfikuje podstawowe prawne uwarunkowania działalności z zakresu zarządzania informacją (UJ, b.d. a; UJ, b.d. b), z tą różnicą, że absolwent posiadający kwalifikacje II stopnia rozumie także konieczność zarządzania zasobami własności intelektualnej.

Zgodnie z planem studiów stacjonarnych I stopnia na kierunku Zarządzanie informacją, wśród modułów kształcenia znajduje się wykład z ochrony własności intelektualnej jako przedmiot obligatoryjny realizowany w wymiarze 30 godzin na trzecim roku studiów (w semestrze piątym) z wykorzystaniem prezentacji multimedialnej. Założone efekty kształcenia w odniesieniu do tego przedmiotu przewidują, że student:

- w zakresie wiedzy

- właściwie uzasadnia konieczność zarządzania zasobami własności intelektualnej w działalności informacyjnej, bibliotecznej, wydawniczej i archiwalnej,

- zna i rozumie podstawowe pojęcia, regulacje i zasady z zakresu ochrony własności intelektualnej i prawa autorskiego,

- przedstawia uprawnienia przysługujące podmiotom praw autorskich i pokrewnych oraz praw własności przemysłowej, oraz ich czas trwania,

- poprawnie posługuje się terminologią z zakresu ochrony własności intelektualnej

- w zakresie umiejętności

- analizuje w podstawowym zakresie umowy z zakresu własności intelektualnej, rozpoznaje rodzaje tych umów, przesłanki ich ważności, skutki;

- rozpoznaje przedmioty własności intelektualnej, z odróżnieniem prawa autorskiego i praw pokrewnych oraz praw własności przemysłowej,

- uwzględnia podstawowe przepisy prawa własności intelektualnej w odniesieniu do instytucji funkcjonujących w obszarze działalności informacyjnej, bibliotecznej, wydawniczej i archiwalnej

- w zakresie kompetencji społecznych

- uświadamia sobie wpływ rozwoju nauki i techniki na kształtowanie systemu ochrony własności intelektualnej.

Wiedza przekazywana studentom zarządzania informacją na poziomie studiów I stopnia uwzględnia międzynarodowy wymiar ochrony własności intelektualnej z odniesieniem do dwóch podstawowych umów międzynarodowych - Konwencji paryskiej z 20 marca 1883 r. o ochronie wtasności przemystowej oraz Konwencji berneńskiejz 9 września 1886 r. o ochronie 
dziet literackich $i$ artystycznych. Zwraca się uwagę na ideę utworzenia uniwersalnej organizacji międzynarodowej funkcjonującej w obszarze ochrony własności intelektualnej, co znalazło odzwierciedlenie w Konwencji o ustanowieniu Światowej Organizacji Własności Intelektualnej (WIPO/ OMPI) sporządzonej w Sztokholmie 16 lipca 1967 r. Ponadto, treści wykładu obejmują ważniejsze umowy i porozumienia międzynarodowe administrowane przez WIPO, także Porozumienie w sprawie handlowych aspektów praw własności intelektualnej (TRIPS) z 15 kwietnia 1994 r. przyjęte pod egidą Światowej Organizacji Handlu (WTO), Konwencję o udzielaniu patentów europejskich (Konwencja o patencie europejskim) sporządzonej w Monachium 5 października 1973 r. Dla studentów zarządzania informacją szczególnie ważne są treści dotyczące znaczenia własności intelektualnej w gospodarce opartej na wiedzy, która - według OECD - opiera się na generowaniu, dystrybucji oraz zastosowaniu wiedzy i informacji (OECD, 1999, 82). Zakres przekazywanej wiedzy zawiera znajomość reguł i zasad ochrony własności intelektualnej w działalności gospodarczej, w budowaniu strategii danej organizacji. Jest to istotne, albowiem w epoce globalizacji i rynku konkurencji nowe technologie informacyjno-komunikacyjne wpłynęły na sposób prowadzenia działalności gospodarczej oraz rozpowszechniania produktów i usług na rynku cyfrowym. Treści wykładu dotyczące prawa własności przemysłowej obejmują prawo patentowe, w ramach którego studenci zapoznają się m.in. z definicją wynalazku, kategoriami wynalazków, wyłączeniami ustawowymi, przesłankami zdolności patentowej (poziom wynalazczy, nowość, przemysłowe stosowanie). Poznają procedurę krajową w odniesieniu do udzielania patentów oraz procedurę udzielania patentów europejskich. Obok prawa patentowego, studenci nabywają wiedzę o znakach towarowych (pojęcie, funkcje, rodzaje), wzorach przemysłowych i w ograniczonym zakresie o innych przedmiotach własności przemysłowej.

W toku wykładu prezentowane są treści z zakresu prawa autorskiego i praw pokrewnych, w tym m.in. źródła prawa autorskiego w wymiarze międzynarodowym, unijnym i krajowym, ze szczególnym uwzględnieniem ustawy o prawie autorskim i prawach pokrewnych. Omawiane są też zagadnienia dotyczące utworu jako przedmiotu prawa autorskiego, podmiotów prawa autorskiego, rodzajów utworów (współautorskie, zbiorowe, pracownicze i inne). Studenci poznają autorskie prawa osobiste i autorskie prawa majątkowe. Osobną kwestią pozostaje dozwolony użytek osobisty i publiczny. Ponadto, treści wykładu obejmują także problematykę plagiatu - pojęcie, istota i rodzaje. Szczegółowe treści wykładu przedstawia tabela 2.

Plan studiów stacjonarnych II stopnia na kierunku zarządzanie informacją o profilu ogólnoakademickim w ramach modułu specjalizacji "Infobrokering i wywiad rynkowy” (75 godzin, wykład i laboratorium) uwzględnia przedmiot z zakresu podstaw własności przemysłowej (15 godzin laboratorium). W ramach zajęć studenci - na podstawie wybranych dokumentów Unii Europejskiej - zapoznają się z problematyką jednolitego rynku w obszarze własności intelektualnej w kontekście przyszłych potrzeb nowoczesnej gospodarki, analizują znaczenie własności intelektualnej dla sfery biznesu, zwłaszcza dla obszaru infobrokeringu i wywiadu rynkowego. Stosując metodę case study, prezentują wzory użytkowe, znaki towarowe, przykłady dobrych praktyk w odniesieniu do wybranych aspektów pracy brokera informacji, ze szczególnym uwzględnieniem ochrony własności intelektualnej (analiza na przykładzie ośrodków innowacji i przedsiębiorczości w Polsce). Ponadto, zajęcia obejmują zagadnienia zarządzania zasobami własności intelektualnej w działalności brokera informacji. 
Tab. 2. Zakres tematyczny przedmiotu „Ochrona własności intelektualnej” na studiach stacjonarnych I stopnia zarządzanie informacją na Uniwersytecie Jagiellońskim.

Na podstawie realizowanego wykładu z zakresu ochrony własności intelektualnej na kierunku zarządzanie informacją na Wydziale Zarządzania i Komunikacji Społecznej Uniwersytetu Jagiellońskiego (rok akad. 2019/2020)

\begin{tabular}{|c|c|}
\hline \multicolumn{2}{|r|}{ OCHRONA WŁASNOŚCI INTELEKTUALNEJ } \\
\hline \multicolumn{2}{|r|}{ Prawo własności przemysłowej } \\
\hline $\begin{array}{l}\text { Zarys światowego systemu } \\
\text { ochrony własności } \\
\text { intelektualnej }\end{array}$ & $\begin{array}{l}\text { Definicje głównych rodzajów praw własności intelektualnej wg } \\
\text { WIPO/OMPI: prawo autorskie (copyright) i prawa pokrewne; } \\
\text { własność przemysłowa } \\
\text { Najważniejsze regulacje prawne. Rodzaje umów, ich charakterys- } \\
\text { tyka } \\
\text { Elementarne zasady prawa chroniącego własność intelektualną. }\end{array}$ \\
\hline $\begin{array}{l}\text { Elementy prawa własności } \\
\text { przemysłowej }\end{array}$ & $\begin{array}{l}\text { Źródła prawa (akty prawa międzynarodowego; akty prawa wspól- } \\
\text { notowego; akty prawa polskiego) } \\
\text { Pojęcie prawa własności przemysłowej. Główne dziedziny prawa } \\
\text { własności przemysłowej } \\
\text { Własność intelektualna - pojęcie. Własność przemysłowa a włas- } \\
\text { ność intelektualna } \\
\text { Prawo własności przemysłowej w Polsce. Ogólna charakterystyka } \\
\text { ustawy. Rola Urzędu Patentowego. Zadania. Rejestry prowadzone } \\
\text { przez Urząd Patentowy. }\end{array}$ \\
\hline Prawo patentowe & $\begin{array}{l}\text { Źródła prawa (akty prawa międzynarodowego; akty prawa pol- } \\
\text { skiego) } \\
\text { Pojęcie wynalazku. Kategorie wynalazków. Wyłączenia ustawowe } \\
\text { z zakresu pojęcia wynalazku } \\
\text { Podmioty praw do wynalazków } \\
\text { Przesłanki zdolności patentowej } \\
\text { Wynalazki wyłączone spod ochrony prawnej } \\
\text { Procedura rejestracji wynalazku w Polsce. Opłaty, rozpatrywanie } \\
\text { zgłoszenia, decyzje UP w sprawie udzielenia patentu } \\
\text { Procedura rejestracji wynalazku w Unii Europejskiej. } \\
\text { Treść patentu. Ograniczenia patentu } \\
\text { Własność przemysłowa - umowy licencyjne. Pojęcie, rodzaje } \\
\text { umów } \\
\text { Unieważnienie patentu } \\
\text { Wygaśnięcie patentu. }\end{array}$ \\
\hline Prawo znaków towarowych & $\begin{array}{l}\text { Źródła prawa } \\
\text { Znak towarowy - pojęcie, funkcje, rodzaje } \\
\text { Procedura rejestracji znaku towarowego w Polsce. }\end{array}$ \\
\hline $\begin{array}{l}\text { Prawo wzorów } \\
\text { przemysłowych. } \\
\text { Inne przedmioty ochrony } \\
\text { własności przemysłowej }\end{array}$ & $\begin{array}{l}\text { Wzór przemysłowy - pojęcie } \\
\text { Przesłanki zdolności rejestrowej wzoru } \\
\text { Pojęcie oznaczenia geograficznego } \\
\text { Pojęcie wzoru użytkowego. Przesłanki zdolności ochronnej wzo- } \\
\text { ru użytkowego } \\
\text { Pojęcie topografii układu scalonego. }\end{array}$ \\
\hline
\end{tabular}




\begin{tabular}{|c|c|}
\hline \multicolumn{2}{|r|}{ Prawo autorskie i prawa pokrewne } \\
\hline Prawo autorskie & $\begin{array}{l}\text { Źródła prawa autorskiego (akty prawa międzynarodowego; akty } \\
\text { prawa wspólnotowego; akty prawa polskiego) } \\
\text { Prawo autorskie w Polsce - rozwój } \\
\text { Prawo autorskie - pojęcie (aspekt przedmiotowy i podmiotowy). } \\
\text { Modele prawa autorskiego. Zasady prawa autorskiego. }\end{array}$ \\
\hline $\begin{array}{l}\text { Utwór jako przedmiot } \\
\text { prawa autorskiego }\end{array}$ & $\begin{array}{l}\text { Źródła prawa } \\
\text { Utwór - pojęcie. Przesłanki uznania danego wytworu za utwór. } \\
\text { Ustalenie a utrwalenie utworu. Katalog utworów według prawa } \\
\text { autorskiego. Wyłączenia ustawowe. }\end{array}$ \\
\hline Podmiot prawa autorskiego & $\begin{array}{l}\text { Źródła prawa } \\
\text { Twórca jako podmiot prawa autorskiego. Domniemanie autorstwa } \\
\text { Podmioty autorskich praw majątkowych inne niż twórca Nabycie } \\
\text { pierwotne, nabycie pochodne. Instytucje naukowe. Dzieła anoni- } \\
\text { mowe. }\end{array}$ \\
\hline Rodzaje utworów & $\begin{array}{l}\text { Źródła prawa (akty prawa międzynarodowego; akty prawa } \\
\text { polskiego) } \\
\text { Utwór współautorski - pojęcie i rodzaje. Utwór połączony - poję- } \\
\text { cie. Powstanie utworów połączonych } \\
\text { Utwór zbiorowy - pojęcie. Przykłady. Prawa autorskie do utworu } \\
\text { zbiorowego } \\
\text { Utwór pracowniczy - pojęcie. Nabycie autorskich praw mająt- } \\
\text { kowych do utworu pracowniczego przez pracodawcę Autorskie } \\
\text { prawa osobiste do utworu pracowniczego } \\
\text { Utwór zależny - pojęcie, istota dzieła zależnego Wykonywanie } \\
\text { autorskich praw majątkowych i osobistych do utworu zależnego . } \\
\text { Opracowanie cudzego utworu. Utwór inspirowany. }\end{array}$ \\
\hline $\begin{array}{l}\text { Autorskie prawa } \\
\text { majątkowe }\end{array}$ & $\begin{array}{l}\text { Źródła prawa } \\
\text { Autorskie prawa majątkowe - pojęcie i charakter } \\
\text { Treść autorskich praw majątkowych } \\
\text { Pola eksploatacji - pojęcie. Katalog pól według ustawy Uprawnie- } \\
\text { nia majątkowe } \\
\text { Sposoby pochodnego nabycia autorskich praw majątkowych } \\
\text { Czas ochrony autorskich praw majątkowych. }\end{array}$ \\
\hline $\begin{array}{l}\text { Dozwolony użytek osobisty } \\
\text { i publiczny }\end{array}$ & $\begin{array}{l}\text { Źródła prawa } \\
\text { Dozwolony użytek - pojęcie. Istota dozwolonego użytku Rodzaje } \\
\text { według ustawy. Cele. Zasady korzystania } \\
\text { Dozwolony użytek osobisty - pojecie, warunki korzystania (zakres } \\
\text { własnego użytku osobistego; wyłączenia) } \\
\text { Dozwolony użytek publiczny - pojęcie. Cele informacyjne, oświa- } \\
\text { towe, naukowe, gospodarcze, państwowe } \\
\text { Prawo cytatu. Przesłanki dozwolonego cytatu. }\end{array}$ \\
\hline Autorskie prawa osobiste & $\begin{array}{l}\text { Autorskie prawa osobiste - pojęcie, cechy } \\
\text { Katalog autorskich praw osobistych. }\end{array}$ \\
\hline
\end{tabular}




\begin{tabular}{|l|l|}
\hline Plagiat & $\begin{array}{l}\text { Źródła prawa } \\
\text { Plagiat - pojęcie, istota, rodzaje } \\
\text { Plagiat - odpowiedzialność cywilna. Plagiat - odpowiedzialność } \\
\text { karna. }\end{array}$ \\
\hline Prawa pokrewne & $\begin{array}{l}\text { Akty prawa polskiego } \\
\text { Prawa pokrewne - pojęcie, charakter, rodzaje } \\
\text { Przedmiot praw pokrewnych do pierwszego wydania. Przedmiot } \\
\text { praw pokrewnych do wydania naukowego i krytycznego. Podmiot } \\
\text { praw do wydań naukowych i krytycznych. Czas trwania praw do } \\
\text { pierwszych wydań oraz wydań naukowych i krytycznych. }\end{array}$ \\
\hline
\end{tabular}

Także w ramach modułu specjalizacji „Obiekty i kolekcje cyfrowe” realizowany jest przedmiot dotyczący wybranych elementów prawa autorskiego. Treści z zakresu ochrony własności intelektualnej występują również w ramach wykładu „Zarządzanie informacją w sektorze nauki” (30 godzin), m.in. w odniesieniu do zarządzania informacją w kontekście komercjalizacji wyników badań naukowych i prac rozwojowych, zarządzania własnością intelektualną i transferu wiedzy pomiędzy uczelniami wyższymi i przedsiębiorstwami.

\section{Podsumowanie}

W świecie gospodarki opartej na wiedzy kształcenie w zakresie ochrony własności intelektualnej ma kluczowe znaczenie. Uczelnie wyższe, w tym uniwersytety coraz szerzej współpracują z instytucjami środowiska gospodarczego, w ramach tzw. trójkąta wiedzy, przez co rozumie się

(...) ustrukturyzowane partnerstwo ze środowiskiem biznesu (w tym MŚP) stwarza uniwersytetom możliwości dzielenia się wynikami badań, prawami własności intelektualnej, patentami i licencjami (...) (Komunikat KE, 2006, 6).

Programy nauczania powinny odpowiadać wymogom gospodarki wiedzy, oferując studentom możliwości kształtowania umiejętności związanych z przedsiębiorczością, kreatywnością oraz innowacyjnością, a z tym wiążą się treści z zakresu ochrony własności intelektualnej. Jak wykazały badania, akty wykonawcze do ustawy Prawo o szkolnictwie wyższym z lat 2002-2011, określające standardy nauczania dla poszczególnych kierunków studiów i poziomów kształcenia, usankcjonowały nauczanie akademickie studentów w odniesieniu do ochrony własności intelektualnej. Poprzednio obowiązujące rozporządzenie z 2016 r. w związku z ustawą o Zintegrowanym Systemie Kwalifikacji, jak również obecnie obowiązujące rozporządzenie do nowej ustawy Prawo o szkolnictwie wyższym i nauce z 2018 r. określają w zakresie wiedzy znajomość i rozumienie podstawowych pojęć i zasad z zakresu ochrony własności przemysłowej i prawa autorskiego. Przykład kierunku studiów Zarządzanie informacją na Wydziale Zarządzania i Komunikacji Społecznej Uniwersytetu Jagiellońskiego obrazuje, że wiedza dotycząca ochrony własności intelektualnej jest niezbędna w kształceniu umiejętności praktycznych, rozwijaniu i doskonaleniu kompetencji zawodowych związanych z szeroko ujmowaną profesją specjalisty zarządzania informacją. Multidyscyplinarność obszaru ochrony własności intelektualnej w wymiarze społecznym, 
ekonomicznym, kulturowym i technologicznym może stanowić dla studentów interesującą, stymulującą perspektywę, uwzględniającą wyzwania gospodarki opartej na wiedzy.

\section{Bibliografia}

Dekret (1919a). Dekret o ochronie wzorów rysunkowych i modeli. Dz.Pr.P.P 13, poz. 138.

Dekret (1919b). Dekret o ochronie znaków towarowych. Dz.Pr.P.P 13, poz. 139.

Dekret (1919c). Dekret o patentach na wynalazki. Dz.Pr.P.P 13, poz. 137.

Komunikat KE (2006). Komunikat Komisji do Rady i Parlamentu Europejskiego - Realizacja programu modernizacji dla uniwersytetów - Edukacja, badania naukowe i innowacje /COM/2006/0208 końcowy [online]. EUR-Lex.europa [20.12.2019], https://eur-lex.europa.eu/legal-content/PL/TXT/ PDF/?uri=CELEX:52006DC0208\&qid $=1540986773793 \&$ from $=$ PL

Komunikat KE (2010). Komunikat komisji Europa 2020 Strategia na rzecz inteligentnego i zrównoważonego rozwoju sprzyjającego włączeniu społecznemu EUROPA 2020 Strategia na rzecz inteligentnego i zrównoważonego rozwoju sprzyjającego włączeniu społecznemu

COM/2010/2020 końcowy [online]. EUR-Lex.europa [20.12.2019], https://eur-lex.europa.eu/legal-content/PL/TXT/?qid=1536660329121\&uri=CELEX:52010DC2020

Komunikat KE (2011). Komunikat Komisji do Parlamentu Europejskiego, Rady, Europejskiego Komitetu Ekonomiczno-Społecznego i Komitetu Regionów Działania na rzecz wzrostu gospodarczego i zatrudnienia - plan modernizacji europejskich systemów szkolnictwa wyższego KOM/2011/0567 wersja ostateczna [online]. EUR-Lex.europa [20.12.2019], https://eur-lex.europa.eu/legal-content/ $\mathrm{PL} / \mathrm{TXT} / \mathrm{PDF} /$ ?uri=CELEX:52011DC0567\&from $=\mathrm{PL}$

Komunikat KE (2017a). Komunikat Komisji do Parlamentu Europejskiego, Rady, Europejskiego Komitetu Ekonomiczno-Społecznego i Komitetu Regionów dotyczący odnowionego programu UE dla szkolnictwa wyższego COM/2017/0247 final [online]. EUR-Lex.europa [20.12.2019], https:// eur-lex.europa.eu/legal-content/PL/TXT/PDF/?uri=CELEX:52017DC0247\&from=PL

Komunikat KE (2017b). Komunikat Komisji do Parlamentu Europejskiego, Rady, Europejskiego Komitetu Ekonomiczno-Społecznego Zrównoważony system egzekwowania praw własności intelektualnej odpowiadający dzisiejszym wyzwaniom społecznym COM/2017/0707 final [online]. EUR-Lex. europa [20.12.2019], https://eur-lex.europa.eu/legal-content/PL/TXT/?qid=1537742184569\&uri=CELEX:52017DC0707

OECD (1999). The Future of the Global Economy. Towards and Long Boom? . Paris: OECD [online]. OECD [20.12.2019], https://www.oecd.org/futures/35394025.pdf

Oświadczenie (1922). Oświadczenie Rządowe o przystąpieniu Polski do Międzynarodowego Związku Ochrony Własności Przemysłowej. Dz.U. 8, poz. 58.

Porozumienie (1994). Porozumienie w sprawie handlowych aspektów praw własności intelektualnej [online]. Dz.U. L 336 z 23.12.1994, s. Polskie wydanie specjalne: Rozdział 11 Tom 021 s. 305 324 [28.04.2020], https://eur-lex.europa.eu/legal-content/PL/TXT/PDF/?uri=CELEX:21994A1223(17)\&from $=$ PL

Protokół RGNiSW (2004). Protokół XV posiedzenia plenarnego Rady Głównej Nauki i Szkolnictwa Wyższego w okresie 15 lipca 2004 r. [online]. Rada Główna Nauki i Szkolnictwa Wyższego [20.12.2019], http://www.rgnisw.nauka.gov.pl/protokoly-2004/protokol-xv-posiedzeniaplenarnego-rady-glownej-szkolnictwa-wyzszego-w-dniu-15-lipca-2004-r-.html

Rezolucja PE (2010). Dialog uczelni i przedsiębiorstw: Nowe partnerstwo na rzecz modernizacji uczelni. Rezolucja Parlamentu Europejskiego z dnia 20 maja 2010 r. w sprawie dialogu środowisk akademickich z przedsiębiorcami: nowego partnerstwa na rzecz modernizacji uczelni w Europie (2009/2099 (INI)) (Dialog uczelni i przedsiębiorstw: Nowe partnerstwo na rzecz modernizacji uczelni Rezolucja Parlamentu Europejskiego z dnia 20 maja 2010 r. w sprawie dialogu środowisk 
akademickich z przedsiębiorcami: nowego partnerstwa na rzecz modernizacji uczelni w Europie (2009/2099 (INI)) (Dz.U. C 161E z 31.5.2011) [online]. EUR-Lex.europa [20.12.2019], https://eur-lex.europa.eu/legal-ontent/PL/TXT/?qid=1540482986538\&uri=CELEX:52010IP0187

Rozporządzenie (2018a). Ocena skutków regulacji. Projekt z dnia 25 lipca 2018 r. Rozporządzenie Ministra Nauki i Szkolnictwa Wyższego z dnia ... 2018 r. w sprawie charakterystyk drugiego stopnia efektów uczenia się dla kwalifikacji na poziomach 6-8 Polskiej Ramy Kwalifikacji [online], [20.12.2019], https://legislacja.rcl.gov.pl/docs//506/12314202/12524000/12524001/dokument351499.pdf

Rozporządzenie (2018b). Projekt z dnia 25 lipca 2018 r. Rozporządzenie Ministra Nauki i Szkolnictwa Wyższego z dnia ... 2018 r. w sprawie charakterystyk drugiego stopnia efektów uczenia się dla kwalifikacji na poziomach 6-8 Polskiej Ramy Kwalifikacji [online], [20.12.2019], https://legislacja. rcl.gov.pl/projekt/12314202

Rozporządzenie (2018c). Rozporządzenie Ministra Nauki i Szkolnictwa Wyższego z dnia 14 listopada 2018 r. w sprawie charakterystyk drugiego stopnia efektów uczenia się dla kwalifikacji na poziomach 6-8 Polskiej Ramy Kwalifikacji [online], [20.12.2019], http://prawo.sejm.gov.pl/isap. nsf/download.xsp/WDU20180002218/O/D20182218.pdf

Soetendorp R., Haberman M., Smith S. (2016). University IP Policies: Perception and Practice [online]. WIPO Magazine, 6 [20.12.2019], https://www.wipo.int/wipo_magazine/en/2016/06/ article_0009.html

Świętosławski, W. (1927). Zadania uczelni akademickich jako ośrodków kształcenia mas młodzieży. Nauka Polska, 8, 6-14.

The Future of the Global Economy. Towards and Long Boom? (1999). Paris: OECD, [online], [20.12.2019], https://www.oecd.org/futures/35394025.pdf

Uchwała (1971). Uchwała nr 35 Rady Ministrów z 12 lutego 1971 r. w sprawie rozwoju informacji naukowej, technicznej i ekonomicznej (M.P. $1971 \mathrm{nr}$ 14, poz. 104).

Willinsky, J.(2017). Intellectual Property and Education. Oxford Research Encyclopedias. http://dx.doi. org/10.1093/acrefore/9780190264093.013.230

Vall, du M. (2007). Międzywydziałowe nauczanie własności intelektualnej: doświadczenia Uniwersytetu Jagiellońskiego, s. 1-4. Wypowiedź podczas konferencji nt. „Upowszechnianie wiedzy o własności intelektualnej w uniwersytetach" zorganizowanej w Warszawie przez Urząd Patentowy RP 25 maja 2007 r. [online], [20.12.2019], https://www.uprp.pl/uprp/_gAllery/18/81/18819/ Michal_du_Vall.pdf

Zalecenie (2008). Zalecenie Komisji z dnia 10 kwietnia 2008 r. w sprawie zarządzania własnością intelektualną w ramach działań związanych z transferem wiedzy oraz Kodeks postępowania dla uczelni wyższych i innych publicznych instytucji badawczych (notyfikowana jako dokument $\mathrm{nr}$ C(2008) 1329) (Tekst mający znaczenie dla EOG) Dz.U. L 146 z 2008 r. [online], [20.12.2019], https://eur-lex.europa.eu/legal-content/PL/TXT/?qid=1585929422580\&uri=CELEX:32008H0416

Załącznik (2018). Załącznik do rozporządzenia Ministra Nauki i Szkolnictwa Wyższego z dnia 14 listopada 2018 r. (poz. 2218) Charakterystyki drugiego stopnia efektów uczenia się dla kwalifikacji na poziomach 6-8 Polskiej Ramy Kwalifikacji typowe dla kwalifikacji uzyskiwanych w ramach systemu szkolnictwa wyższego i nauki po uzyskaniu kwalifikacji pełnej na poziomie 4 [online], [20.12.2019], http://prawo.sejm.gov.pl/isap.nsf/download.xsp/WDU20180002218/O/D20182218.pdf 


\title{
Intellectual Property Protection at the University Education in Information Management and Related Fields in Poland
}

\begin{abstract}
Purpose/Thesis: The aim of the research was to draw attention to the importance of familiarity with the intellectual property protection knowledge in the field of intellectual property protection including industrial property and copyright law - in the context of new, dynamically developing information and communication technologies, the digital economy and the university education of information professionals - information management specialists, librarians, information brokers or documentation management specialists.

Approach/Methods: The article reviews the state of scholarship to discuss intellectual property protection. Using the data from the POL-on higher education information system and websites of individual universities, the study distinguishes various programs addressed to information professionals. The author examined if the programs and training modules contain the issue of intellectual property protection.

Results and conclusions: The study focused on Polish educational standards, particularly teaching on intellectual property protection. They aim to teach knowledge, skills and social competences regarding the protection of industrial property and copyright. With information management programs offered by the Institute of Information Studies (previously Institute of Information and Library Science) at the Faculty of Management and Social Communication of the Jagiellonian University, analyzing the plans of 1st and 2nd cycle studies and learning modules, the author examined learning outcomes regarding intellectual property protection, showing the need to introduce more systematic teaching in this area and indicating the scope of knowledge conveyed to students of information management. Originality/Value: The issue presented has not yet been the subject of wider consideration.
\end{abstract}

Keywords

Education standards. European Union. Information management. Intellectual property protection. Poland. University studies.

Dr hab. DIANA PIETRUCH-REIZES, profesor Uniwersytetu Jagiellońskiego - doktor habilitowany nauk humanistycznych, dr nauk prawnych. Pracownik Instytutu Studiów Informacyjnych Uniwersytetu Jagiellońskiego. Cztonek Rady Towarzystw Naukowych PAN. Prezes Polskiego Towarzystwa Informacji Naukowej (PTIN). Dyscyplina naukowa: nauki o komunikacji spotecznej i mediach. Zainteresowania naukowe: nauka o informacji jako dziedzina interdyscyplinarna, informacja europejska, informacja prawna i informacja parlamentarna $w$ aspekcie historycznym $i$ wspótczesnym, zarzqdzanie informacja w sektorze nauki, zarzadzanie informacja w kontekście ochrony wtasności intelektualnej. Ostatnio opublikowata: Podstawy prawne w zarzadzaniu informacją w kontekście ochrony własności intelektualnej (W: W. Babik (red.), Zarządzanie informacją, Warszawa, 2019); Transfer of knowledge and new technologies from science to the economy (In: Theorie, Semantik und Organisation von Wissen, 2017); Zarzadzanie informacja w nauce w świetle dokumentów Unii Europejskiej: wybrane zagadnienia (W: W M. Bugdol, P. Jedynak (red.), Jakość zarządzania: refleksje, wymiary, problemy, Kraków, 2017).

Kontakt $z$ autorka:

diana.pietruch-reizes@uj.edu.pl

Instytut Studiów Informacyjnych

Wydziat Zarzadzania i Komunikacji Społecznej

Uniwersytet Jagielloński

ul. prof. Stanisława Łojasiewicza 4

30-348 Kraków 